\title{
Google Meet Application and Media Power Points to Improve IPA Learning Results
}

\author{
Essa Ratih Komalasari \\ SDN 02 PEKUNCEN \\ ratihessa7@gmail.com
}

\section{Article History}

accepted 01/11/2020

approved 08/11/2020

published 15/11/2020

\begin{abstract}
The background of this research is the low courage of the science learning outcomes in grade $V$ SDN 02 Pekuncen. The purpose of this research is to improve the learning outcomes of students in the science muple. The method used in learning is through the Google Meet application using Power Point media. Classroom Action Research is carried out in three cycles, namely planning, implementing, observing, and reflecting. In cycle I there is an increase in learning outcomes from cycle as much as 38\%, from cycle 1 to cycle II experienced a 53\% increase in learning outcomes and cycle II to cycle III as much as $97 \%$. This shows that the use of the Google application to meet the Power Point media can improve student learning outcomes, especially in Class V science muple at SDN 02 Pekuncen.
\end{abstract}

Keywords: Learning outcomes, Google Meet, Power Point, Science

\section{Abstrak}

Latar belakang penelitian ini adalah masih rendahnya hasil belajar IPA pada pembelajaran secara daring pada kelas V SDN 02 Pekuncen.Tujuan penelitian ini adalah untuk meningkatkan hasil belajar peserta didik pada mupel IPA. Metode yang digunakan dalam pembelajaran adalah melalui aplikasi Google Meet menggunakan media Power Point.Penelitian Tindakan Kelas yang dilakukan sebanyak tiga siklus yaitu perencanaan,pelaksanaan,pengamatan,dan refleksi.Pada siklus I terdapat kenaikan hasil belajar dari pra siklus sebanyak $38 \%$,dari siklus 1 ke siklus II mengalami kenaikan hasil belajar $53 \%$ dan siklus II ke siklus III sebanyak 99\%. Hasil ini menunjukkan bahwa penggunaan aplikasi Google meet dengan media Power Point dapat meningkatkan hasil belajar peserta didik khususnya pada mupel IPA Kelas V di SDN 02 Pekuncen

Kata kunci:Hasil belajar,Google Meet,Power Point,IPA

Social, Humanities, and Education Studies (SHEs): Conference Series https://jurnal.uns.ac.id/shes 


\section{PENDAHULUAN}

Dalam suasana masa pandemi covid 19 ini guru harus melakukan pembaruan dengan tujuan meningkatkan efektifitas pembelajaran yang dilaksanakannya. Guru juga harus dapat meningkatkan motivasi dan minat belajar siswa salah satunya adalah menggunakan pembelajaran Daring (dalam jaringan). Mengantisipasi merebaknya virus covid 19 yang mengharuskan siswa belajar dari rumah, maka pembelajaran dilaksanakan secara daring dengan sistem online atau virtual tanpa tatap muka langsung. Jika dilihat dari KBBI Kemendikbud Daring (Dalam Jaringan) adalah akronim dari dalam jaringan, terhubung melalui jejaring komputer, internet, dan sebagainya. Pembelajaran daring ini selain proses belajar mengajar juga termasuk dalam pemberian tugas dan evaluasi. Dengan kata lain, pembelajaran daring adalah metode belajar yang menggunakan model interaktif berbasis internet dan Learning Management System (LMS) seperti menggunakan zoom,googlemeet, whatsaap, dan lainnya.

Pembelajaran daring yang dilakukan kenyataannya saat ini belum lah sesuai antara harapan dan kenyataan, kebanyakan para guru merasakan bahwa motivasi belajar masih rendah. Dengan demikian menyebabkan hasil belajar siswa juga rendah.Pembelajaran daring yang dilakukan selama ini pada SDN 02 Pekuncen masih sebatas menggunakan Whatsaap Grup kelas. Materi yang disampaikan dikirim melalui Whatsapp grup kemudian pengumpulan tugas juga dengan mengirimkan hasil jawaban ke nomor whatsaap guru.Seiring berjalannya waktu terjadi kebosanan dalam pembelajaran yang menyebabkan hasil belajar peserta didik belum mencapai kriteria ketuntasan minimal.Oleh karena itu perlu adanya perubahan dalam pelaksanaan pembelajaran daring yang dilakukan,yaitu dengan menggunakan aplikasi pembelajaran yang dapat menumbuhkan motivasi dan minat belajar IPA sehingga nantinya tujuan pembelajaran dapat tersampaikan dengan baik dan dapat meningkatkan hasil belajar IPA peserta didik.

Hasil belajar merupakan bagian terpenting dalam pembelajaran. Nana Sudjana (2009 :3) mendefinisikan hasil belajar siswa pada hakikatnya adalah perubahan tingkah laku sebagai hasil belajar dalam pengertian yang lebih luas mencakup bidang kognitif,afektif ,dan psikomotorik.Berdasarkan pengertian pengertian tersebut dapat disimpulkan bahwa hasil belajar adalah kemampuan yang dimiliki siswa setelah menerima pengalaman belajarnya.Hasil belajar dapat dilihat melalui kegiatan evaluasi yang bertujuan untuk mendapatkan data pembuktian yang akan menunjukkan tingkat kemampuan siswa dalam mencapai tujuan pembelajaran.Jadi dapat disimpulkan Hasil belajar adalah perubahan tingkah laku sebagai hasil pembelajaran baik bidang kognitif, afektif, dan psikomotorik melalui suatu interaksi tindak belajar dan mengajar.

Penggunaan aplikasi yang digunakan oleh guru dalam pembelajaran daring untuk meningkatkan motivasi siswa dalam belajar IPA adalah menggunakan aplikasi Google Meet. Alasan lain menggunaan aplikasi ini adalah karena dapat di akses dengan mudah oleh para peserta didik menggunakan Smartphone mereka masing masing.Aplikasi Google Meet ini nantinya menyediakan ruang rapat yang disajikan/didaftar oleh guru,kemudian link dibagikan kepada sisiwa untuk dapat mengikuti pembelajaran secara daring. Untuk melaksanakan pembelajaran IPA guru menggunakan media Power Point yang berisi slide -slide materi untuk disampaikan ke siswa dalam kegiatan rapat Google Meet.

Media Power Point digunakan untuk memudahkan penyampaian materi sehingga memudahkan peserta didik memahami visualisasi materi yang ditampilkan dalam slide.Tampilan slide bisa berupa tulisan,gambar,video,ataupun rekaman pembelajaran yang bisa kita sajikan dengan menarik dan dengan tampilan warna yang bisa kita sesuaikan. 


\section{METODE}

Penelitian yang dilakukan adalah Penelitian Tindakan Kelas (PTK) atau Classroom Action Research dengan menggunakan Aplikasi Google Meet dan media Power Point dalam Pembelajaran IPA. Menurut Hopkins (1993), penelitian tindakan kelas diawali dengan perencanaan tindakan (Planning), penerapan tindakan (action), mengobservasi dan mengevaluasi proses dan hasil tindakan (Observation and evaluation). Sedangkan prosedur kerja dalam penelitian tindakan kelas terdiri atas empat komponen, yaitu perencanaan (planning), pelaksanaan (acting), pengamatan (observing), dan refleksi (reflecting), dan seterusnya sampai perbaikan atau peningkatan yang diharapkan tercapai (kriteria keberhasilan).Analisis yang digunakan adalah data kuantitatif dan kualitatif,selain menunjukkan penyajian data berupa angka juga berupa observasi pengaruh penggunaan aplikasi google meet dan media Power Point yang digunakan dalam penelitian dapat meningkatkan hasil belajar IPA.Penelitian Tindakan Kelasini dilakukan pada kelas V SDN 02 Pekuncen Tahun pelajaran 2020/2021 yang dilaksanakan selama tiga siklus.Siklus I pada tanggal 22 Oktober 2020, Siklus II pada tanggal 2 November 2020, dan siklus III pada tanggal 13 November 2020.Teknik pengumpulan data yang digunakan adalah dengan observasi oleh teman sejawat mengenai penggunaan aplikasi Google meet dalam pembelajaran dan penggunaan media Power Point dalam pembelajaran.Serta untuk tes berupa pre test maupun post test daring menggunakan soal pada Google Form

\section{HASIL DAN PEMBAHASAN}

Pelaksanaan peneltian siklus I dilaksanakan satu kali pertemuan,sebelum pelaksanaan siklus I telah diadakan pre test tentang materi IPA mengenai Gangguan pada organ peredaran darah manusia yaitu pada kelas V Tema 4 Subtema 2 Pembelajaran ke 5.Pelaksanaan penelitian dengan pembelajaran daring menggunakan aplikasi Google Meet dan media Power Point dilakukan dengan tahapan Perencanaan,Tindakan,Observasi oleh teman sejawat,kemudian Refleksi.Berdasarkan data yang terkumpul dan setelah diskusi dengan teman sejawat ,saya mencoba menyimpulkan hasil tindakan yang dilakukan dengan table dibawah ini :

Tabel 1. Hasil Pembahasan Siklus 1

\begin{tabular}{|c|c|c|c|c|c|c|c|}
\hline \multirow[b]{2}{*}{ No } & \multirow[b]{2}{*}{ Nama siswa } & \multirow[b]{2}{*}{ KKM } & \multirow[b]{2}{*}{$\begin{array}{l}\text { Nilai Studi } \\
\text { Awal }\end{array}$} & \multicolumn{3}{|c|}{ Siklus 1} & \multirow{2}{*}{ Ket } \\
\hline & & & & Nilai & $\begin{array}{c}\text { Mengalami } \\
\text { Kenaikan }\end{array}$ & $\begin{array}{c}\text { Belum } \\
\text { Mengalami } \\
\text { Kenaikan }\end{array}$ & \\
\hline 1 & Kayla Ramadhani & 65 & 60 & 50 & & $\mathrm{~V}$ & \\
\hline 2 & Afizah Nurul Aeni & 65 & 60 & 60 & & V & \\
\hline 3 & Aldhisa Azzuhra & 65 & 55 & 70 & V & & \\
\hline 4 & Andhika Ade P & 65 & 50 & 50 & & V & \\
\hline 5 & Dwi Arka saputra & 65 & 60 & 60 & & V & \\
\hline 6 & Farel Aska Mustofa & 65 & 50 & 70 & V & & \\
\hline 7 & Faza Arkana & 65 & 65 & 60 & & V & \\
\hline
\end{tabular}


SHEs: Conference Series 3 (3) (2020) 463-469

\begin{tabular}{clccccl}
\hline 8 & Fibri Maulida & 65 & 60 & 70 & $\mathrm{~V}$ & \\
9 & Mahardian Nizzar & 65 & 65 & 80 & $\mathrm{~V}$ & \\
10 & Meyditya Eivelin & 65 & 65 & 90 & $\mathrm{~V}$ & \\
11 & Nafisa Nailal Husna & 65 & 50 & 50 & & $\mathrm{~V}$ \\
12 & Raditia Julianto & 65 & 60 & 60 & $\mathrm{~V}$ \\
13 & Raffa Aldhitama & 65 & 50 & 50 & $\mathrm{~V}$ \\
\hline
\end{tabular}

Berdasarkan table diatas dapat dilihat ada peningkatan hasil belajar IPA kelas $\mathrm{V}$ materi gangguan pada organ peredaran darah manusia ,dimana siswa yang belum tuntas pada nilai studi awal sebanyak 13 siswa mengalami kenaikan pada siklus I tuntas sebanyak 5 siswa dan yang belum tuntas ada 8 siswa.Pada pre test ada 13 siswa yang tidak tuntas Kiteria Ketuntasan Minimal sebesar 65,kemudian pada siklus I hanya 8 sisiwa yang belum Tuntas.

Berdasarkan Refleksi yang dilakukan pada siklus I maka diputuskan untuk melanjutkan ke siklus II.Kegiatan perbaikan pembelajaran pada siklus II ini merupakan kelanjutan dai siklus I dimana peneliti lebih mengoptimalkan kegiatan pembelajara IPA materi gangguan pada organ peredaran darah manusia.Mengoptimalkan pembelajaran daring menggunakan aplikasi Google Meet dan Power Point.Dalam siklus II juga dengan kegiatan Perencanaan, Tindakan, Pengamatan oleh teman sejawat,dan Refleksi.Berdasarkan data yang terkumpul dapat disimpulkan hasil pembelajaran.

Table 2. Hasil Siklus II sebagai berikut

\begin{tabular}{|c|c|c|c|c|c|c|c|}
\hline \multirow[b]{2}{*}{ No } & \multirow[b]{2}{*}{ Nama siswa } & \multirow[b]{2}{*}{ KKM } & \multicolumn{5}{|c|}{ Siklus 2} \\
\hline & & & $\begin{array}{c}\text { Nilai Siklus } \\
1\end{array}$ & Nilai & $\begin{array}{c}\text { Mengalami } \\
\text { Kenaikan }\end{array}$ & $\begin{array}{c}\text { Belum } \\
\text { Mengalami } \\
\text { Kenaikan }\end{array}$ & Ket \\
\hline 1 & Kayla Ramadhani & 65 & 50 & 60 & & V & \\
\hline 2 & Afizah Nurul Aeni & 65 & 60 & 85 & V & & \\
\hline 3 & Aldhisa Azzuhra & 65 & 70 & 80 & V & & \\
\hline 4 & Andhika Ade P & 65 & 50 & 60 & & V & \\
\hline 5 & Dwi Arka saputra & 65 & 60 & 80 & V & & \\
\hline 6 & Farel Aska Mustofa & 65 & 70 & 90 & V & & \\
\hline 7 & Faza Arkana & 65 & 60 & 60 & & V & \\
\hline 8 & Fibri Maulida & 65 & 70 & 60 & & V & \\
\hline 9 & Mahardian Nizzar & 65 & 80 & 95 & V & & \\
\hline 10 & Meyditya Eivelin & 65 & 90 & 90 & V & & \\
\hline 11 & Nafisa Nailal Husna & 65 & 50 & 60 & & V & \\
\hline 12 & Raditia Julianto & 65 & 60 & 60 & & V & \\
\hline 13 & Raffa Aldhitama & 65 & 50 & 50 & & V & \\
\hline
\end{tabular}


Berdasarkan table diatas dapat disimpulkan bahwa tindakan perbaikan pembelajaran pada siklus II belum berhasil maksimal ,karena pada perbaikan pembelajaran siklus II hasil belajar siswa yang tuntas $\mathrm{KKM}(65)$ baru 6 siswa dan masih ada 7 siswa yang nilainya belum mengalami kenaikan atau belum tuntas $\mathrm{KKM}(65)$.Setelah melakukan refleksi pada siklus II maka diputuskan untuk melanjutkan ke siklus III hal ini dilakukan untuk mengetahui penerapan aplikasi google meet dan media Power Point dalam meningkatkan dan mempertahankan hasil belajar peserta didik.Pada siklus III materi IPA yang diajarkan adalah Ekosistem. Hasil belajar peserta didik pada siklus III dapat dilihat dalam table berikut ini

Tabel 3. Hasil Penilaian Pembelajaran IPA siklus III

\begin{tabular}{|c|c|c|c|c|c|c|}
\hline No & Nama siswa & & $\begin{array}{c}\text { Nilai } \\
\text { Siklus } \\
2\end{array}$ & $\begin{array}{c}\text { Nilai } \\
\text { Siklus3 }\end{array}$ & $\begin{array}{l}\text { Mengalami } \\
\text { Kenaikan }\end{array}$ & $\begin{array}{c}\text { Belum } \\
\text { Mengalami } \\
\text { Kenaikan }\end{array}$ \\
\hline 1 & Kayla Ramadhani & 65 & 60 & 80 & $\mathrm{~V}$ & \\
\hline 2 & Afizah Nurul Aeni & 65 & 85 & 100 & V & \\
\hline 3 & Aldhisa Azzuhra & 65 & 80 & 100 & V & \\
\hline 4 & Andhika Ade P & 65 & 60 & 80 & V & \\
\hline 5 & Dwi Arka saputra & 65 & 80 & 93 & V & \\
\hline 6 & Farel Aska Mustofa & 65 & 90 & 100 & V & \\
\hline 7 & Faza Arkana & 65 & 60 & 87 & V & \\
\hline 8 & Fibri Maulida & 65 & 60 & 93 & V & \\
\hline 9 & Mahardian Nizzar & 65 & 95 & 100 & V & \\
\hline 10 & Meyditya Eivelin & 65 & 90 & 100 & V & \\
\hline 11 & Nafisa Nailal Husna & 65 & 60 & 93 & V & \\
\hline 12 & Raditia Julianto & 65 & 60 & 87 & V & \\
\hline 13 & Raffa Aldhitama & 65 & 50 & 87 & $\mathrm{~V}$ & \\
\hline
\end{tabular}

Dari penjelasan tabel diatas dapat dijelaskan bahwa tindakan perbaikam pembelajaran yang dilakukan pada siklus III sudah berhasil maksimal.Dari hasil belajar yang diperoleh secara klasikal dari 13 siswa mengalami kenaikan dan tuntas KKM (65). Grafik rekapitulasi hasil belajar IPA dapat disajikan sebagai berikut : 


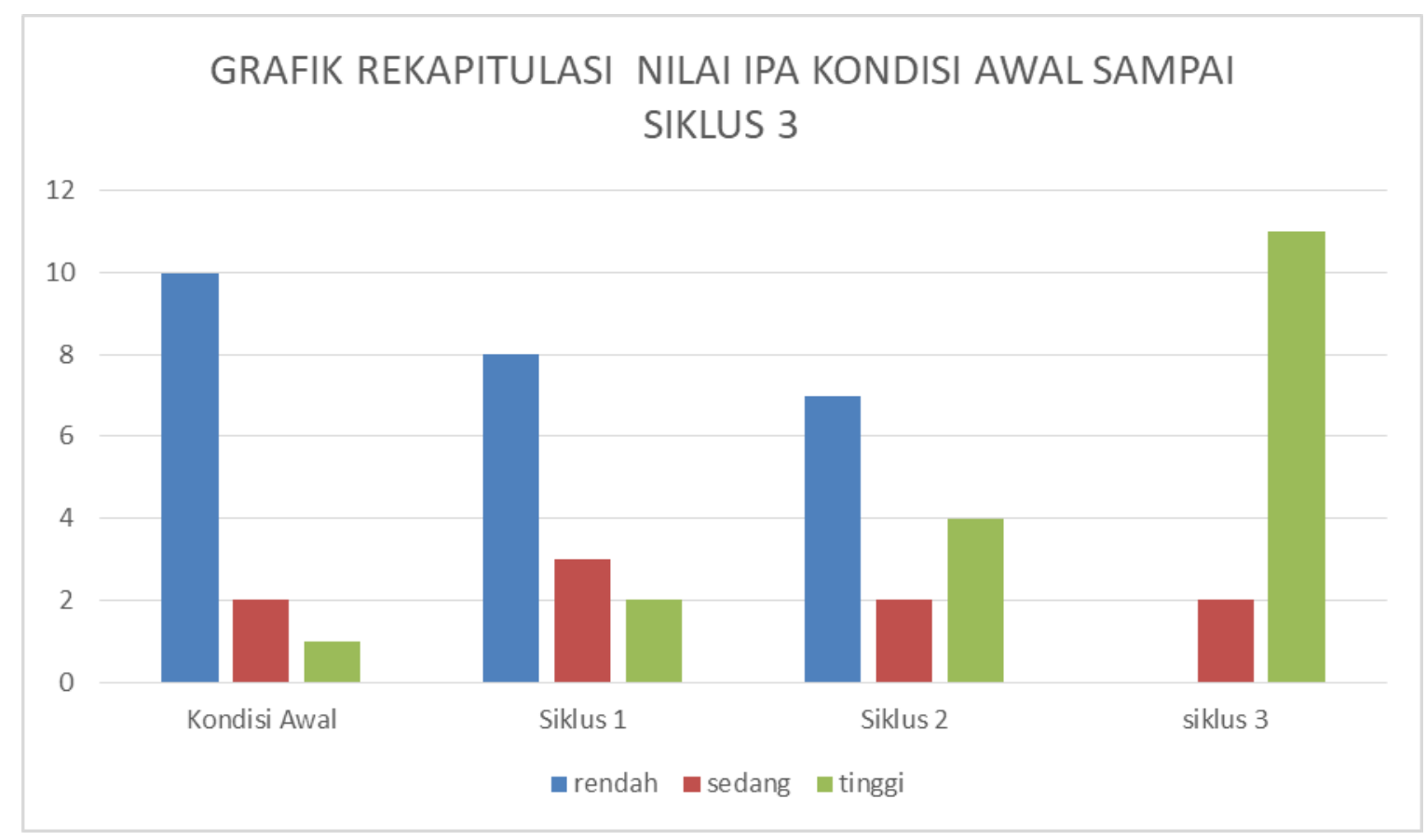

Dari grafik diatas dapat dipastikan perbaikan pembelajaran dari kondisi awal,sampai ketiga siklus yang dilaksanakan mengalami kenaikan.Dapat dipastikan penggunaan aplikasi Google meet dengan media Power point dapat meningkatkan hasil belajar peserta didik pada pembelajaran IPA kelas V di SDN 02 Pekuncen.

\section{SIMPULAN}

Penggunaan aplikasi Google meet dengan media Power point dalam pembelajaran daring dapat meningkatkan hasil belajar peserta didik pada mupel IPA materi gangguan pada organ peredaran darah manusia.Peningkatan yang terjadi karena penggunaan aplikasi Google Meet dengan media Power point mengurangi rasa bosan peserta didik dalam melakukan pembelajaran daring sehingga minat mengikuti pembelajaran lebih meningkat ,penyampaian materi juga lebih tersampaikan dengan baik karena guru memanfaatkan adanya slide dalam PPT yang disajikan untuk menulis materi berupa tulisan,gambar ,rekaman suara,maupun video pembelajaran menyebabkan hasil belajar menjadi lebih maksimal.Berdasarkan penelitian yang dilaksanakan pembelajaran daring menggunakan aplikasi Google Meet dan media Power point sangat cocok digunakan dalam keadaan pandemic seperti sekarang ini,apalagi dalam kondisi belajar dari rumah.Peserta didik akan lebih antusias dalam mengikuti pembelajaran dan materi yang disampaikan juga dapat diterima dengan lebih berkesan.

\section{DAFTAR PUSTAKA}

Andayani,dkk.2011.Pemantapan Kemampuan Profesional.Jakarta :Universitas Terbuka

Arikunto,Suharsini.1990.Pengertian prestasi hasil belajar.http://www.sunartombs.wrodpress.com/2009/01/05pengertian+prestasi+b elajar diakses 20 November 2020

Dananjaya Utomo,2010.Media Pembelajaran Aktif.Bandung:Nuansa

(https://tirto.id/mengenal-google-meet-cara-kerja-hingga-fitureFTx diakses tanggal 20 November 2020)

(https://bathraedu.wordpress.com/2015/05/02/media-pembelajaran-power-point/ diakses tanggal 21 November 2020) 
SHEs: Conference Series 3 (3) (2020) 463- 469

Samatowa,Usman.2011.Pembelajaran IPA di Sekolah Dasar.(Jakarta:Indeks)

Sudjana,N.2009. Penilaian Hasil dan Proses Belajar Mengajar.Bandung: PT Remaja Rosdakaya

Syah,Muhibin.2004.Psikologi Pendidikan.Bandung:Remaja Rosdakarya Tanireja,T dkk.2010.Penelitian Tindakan Kelas untuk Pengembangan Profesi Guru,Praktik,Praktis,dan Mudah. Bandung:Alfabeta

Wardani,I.G.A.K,dkk,2002.Penelitian Tindakan Kelas.Jakarta:Universitas Terbuka 